\title{
Analisis Hubungan Pengetahuan Terhadap Kepatuhan Terapi Pada Pasien Hipertensi di Puskesmas Pucang Sawit Surakarta
}

\author{
Yeni Farida ${ }^{1 *}$, Yumna Zulfa Salsabila ${ }^{2}$, Alfiani Amsari ${ }^{2}$, Rasmaya Niruri ${ }^{1}$, Adi \\ Yugatama $^{1}$, Nestri Handayani ${ }^{1}$ dan Fea Prihapsara ${ }^{1}$ \\ ${ }^{1}$ Program Studi Farmasi, Fakultas Matematika dan Ilmu Pengetahuan Alam, Universitas Sebelas Maret, Jl. Ir. \\ Sutami 36A, Surakarta, Indonesia, 57126. \\ ${ }^{2}$ Program Studi D3 Farmasi, Sekolah Vokasi, Universitas Sebelas Maret, Jl. Ir. Sutami 36A, Surakarta, \\ Indonesia, 57126. \\ *email korespondensi: yenifarida@staff.uns.ac.id \\ Received 09 July 2021, Accepted 25 October 2021, Published 15 November 2021
}

\begin{abstract}
Abstrak: Hipertensi yang tidak terkendali dengan baik dapat meningkatkan terjadinya komplikasi, untuk itu diperlukan kepatuhan pasien dalam terapi hipertensi. Kepatuhan dipengaruhi oleh beberapa faktor, salah satu faktornya adalah pengetahuan. Tujuan penelitian adalah untuk mengetahui hubungan pengetahuan terhadap kepatuhan terapi pasien hipertensi di Puskesmas Pucangsawit Surakarta. Studi crosssectional dilakukan pada populasi pasien hipertensi di Puskesmas Pucang Sawit Surakarta yang memenuhi kriteria inklusi. Sampel ditetapkan dengan kriteria pasien mendapatkan terapi hipertensi minimal 1 bulan, melakukan kunjungan kontrol ke Puskesmas di bulan Maret 2019, serta bersedia menjadi responden yang dibuktikan dengan informed consent. Pengetahuan dinilai dengan kuesioner yang disusun peneliti berdasarkan panduan pharmaceutical care untuk penyakit hipertensi, sedangkan kepatuhan dinilai dengan kuesioner hill-bone. Pengetahuan dikategorikan menjadi baik, cukup dan kurang, sedangkan kepatuhan dikategorikan menjadi patuh dan tidak patuh. Analisis variabel dilakukan dengan uji Pearson correlation. Hasil penelitian menunjukkan bahwa $5,3 \%$ responden memiliki pengetahuan yang baik, $27,1 \%$ berpengetahuan cukup dan $17,6 \%$ berpengetahuan kurang. Tidak terdapat hubungan yang signifikan antara pengetahuan dengan kepatuhan terapi hipertensi pada pasien di Puskesmas Pucang Sawit Surakarta, sedangkan arah korelasinya positif tetapi korelasi antara keduanya sangat lemah $(p=0,319 ; r=0,109)$.
\end{abstract}

Kata kunci: hipertensi; kepatuhan terapi; pengetahuan

Abstract. Relationship of knowledge and drug adherence among hypertension patients in Pucang Sawit, Surakarta Primary Care. Patient adherence is linked to better disease outcomes and is critical to the success of recommended treatments. Adherence can be influenced by a variety of factors, including patients knowledge. This study aimed to determine the relationship of knowledge and therapy adherence among hypertension patients in Pucang Sawit, Surakarta primary care. A cross-sectional study was conducted on a population of hypertensive patients at Pucang Sawit Public Health Center Surakarta who met the inclusion criteria. Patient received hypertension therapy for at least 1 month, made a control visit to the Puskesmas in March 2019, and was willing to become a respondent as evidenced by informed consent were elligible. Patients Knowledge was assessed by a questionnaire prepared by researchers based on pharmaceutical care guidelines for hypertension, while compliance was assessed using a hill-bone questionnaire. Knowledge is categorized into good, sufficient and lacking, while obedience is categorized into obedient and disobedient. Variable analysis was performed using the Pearson correlation test. The results showed that 5,3\% of respondents had good knowledge, $27,1 \%$ had sufficient knowledge and $17,6 \%$ had poor knowledge. There was no significant relationship between knowledge and 
adherence to hypertension therapy in patients at Pucang Sawit Public Health Center Surakarta, while the correlation was positive but very weak $(p=0,319 ; \mathrm{r}=0,109)$

Keywords: hypertension; therapy adherence; knowledge

\section{Pendahuluan}

Hipertensi merupakan suatu penyakit yang ditandai dengan peningkatan tekanan darah di atas nilai normal, yaitu nilai sistolik $\geq 140 \mathrm{mmHg}$ dan atau diastolik $\geq 90 \mathrm{mmHg}$ (Liberty et al., 2017). Riset Kesehatan Dasar (Riskesdas) tahun 2018 menyatakan bahwa prevalensi hipertensi di Indonesia yang didapat melalui pengukuran pada umur $\geq 18$ tahun sebesar $34,1 \%$. Jumlah penduduk yang dinyatakan hipertensi atau tekanan darah tinggi di Provinsi Jawa Tengah pada tahun 2017 sebanyak 1.153 .371 orang atau 12,98\%. Kota Surakarta termasuk daerah dengan tingkat hipertensi tinggi dengan rata-rata 24,2\% (Statistika, 2018).

Penelitian di Nigeria menunjukan bahwa pengetahuan pasien hipertensi di Auchi, Nigeria rendah dan sikap mereka terhadap pengobatan negatif. Pendidikan pasien, motivasi dan pencerahan publik penting untuk menambah pengetahuan (Iyalomhe \& Iyalomhe, 2010). Pengetahuan tentang komplikasi hipertensi akan meningkatkan kepatuhan terhadap terapi antihipertensi (Ghembaza et al., 2014). Penelitian Mesmer juga menyatakan bahwa pasien yang tingkat kepatuhan pengobatannya baik mayoritas memiliki pengetahuan yang baik tentang pengobatan hipertensi $(76,2 \%, \mathrm{p}<0,05)$, komplikasi tekanan darah tinggi $(69,2 \%$, $\mathrm{p}=0,0003)$, dan keparahan hipertensi (90,2\%, p=0,001) (Mesmer et al., 2013).

Hipertensi yang tidak terkontrol atau tidak ditangani dengan baik menyebabkan kerusakan organ yang bersifat irreversible secara bertahap, yang mengarah pada komplikasi yang mengancam jiwa bahkan kematian. Terapi hipertensi melibatkan pemberian obat yang berkelanjutan, serta modifikasi gaya hidup dan kepatuhan dengan serangkaian rekomendasi. Pengetahuan yang buruk tentang kepatuhan terhadap terapi berdampak negatif pada kesadaran dan perilaku pasien dan menimbulkan masalah dalam pengendalian hipertensi (JankowskaPolańska et al., 2016).

Penelitian tentang hubungan pengetahuan dengan kepatuhan terapi sudah banyak dilakukan pada penyakit kronis salah satunya hipertensi (Rahayu et al., 2021). Hal ini ditujukan untuk memberikan masukan terkait edukasi yang masih dibutuhkan dalam meningkatkan keberhasilan terapi pasien. Penelitian tentang hubungan pengetahuan dan kepatuhan pasien hipertensi belum pernah dilakukan di Puskesmas Pucangsawit. Peneliti tertarik melakukan studi lebih lanjut mengenai hubungan pengetahuan terhadap kepatuhan terapi pasien hipertensi di Puskesmas Pucang Sawit Surakarta berdasarkan uraian tersebut. Pemilihan lokasi penelitian didasarkan pada studi pendahuluan di Dinas Kesehatan Surakarta, diketahui data laporan pasien hipertensi di Puskesmas Pucang Sawit masih tinggi. 


\section{Bahan dan Metode}

Penelitian yang dilakukan merupakan penelitian deskriptif analitik, dengan uji korelasi antara pengetahuan dan kepatuhan pasien. Penelitian ini telah mendapatkan persetujuan dari Komisi Etik Penelitian Kesehatan RSUD Dr. Moewardi dengan No. 191/II/HREC/2019. Populasi pada penelitian ini adalah pasien hipertensi di Puskesmas Pucang Sawit Surakarta pada periode Maret 2019. Desain penelitian adalah cross sectional study dengan pengambilan sampel secara purposive sampling yaitu pengambilan sampel yang didasarkan atas pertimbangan dan sesuai dengan kriteria inklusi dan eksklusi. Besar sampel minimal dihitung menggunakan Raosoft sample size calculator untuk desain penelitian cross sectional dengan margin error 5\%, tingkat kepercayaan 95\% dan populasi 100 orang diperoleh sampel minimal adalah 80.

Kriteria inklusi penelitian ini adalah pasien mendapatkan terapi hipertensi minimal 1 bulan, melakukan kunjungan kontrol kedua atau lebih di bulan Maret 2019, serta bersedia menjadi responden yang dibuktikan dengan informed consent. Kriteria eksklusi penelitian ini adalah pasien yang bekerja sebagai tenaga kesehatan, dan pasien yang mengisi kuisoner tidak lengkap.

Instrumen pengumpulan data yang digunakan berupa kuesioner. Kuesioner pengetahuan disusun oleh tim peneliti berdasarkan panduan buku pharmaceutical care (Bina et al., 2006) dan Pedoman Pelayanan Kefarmasian pada hipertensi (Kementrian Kesehatan, 2019). Pengetahuan yang diukur meliputi tekanan darah pasien hipertensi dan target terapi (usia <60 tahun $<140 / 90 \mathrm{mmHg}$, usia $>60$ tahun $<150 / 90 \mathrm{mmHg}$ ), faktor risiko hipertensi, penggunaan obat, kontrol rutin serta life style modification. Kuesioner telah diujikan validitas dan reliabilitas pada 30 responden. Hasilnya diperoleh 11 item pertanyaan valid dengan nilai $r$ hitung > r tabel $(0,361)$ dengan nilai Chronbach alfa 0,6. Data yang diperoleh melalui kuesioner pengetahuan, kemudian dianalisis dengan memberikan skor pada setiap kuesioner berdasarkan ketentuan yang jawaban benar diberi skor 1 dan jawaban salah diberi skor 0 . Hasil akhir adalah hasil total dari semua pernyataan dalam kuesioner, dengan nilai tertinggi adalah 11. Pengetahuan diklasifikasikan berdasarkan nilai yang diperoleh yaitu $>75 \%$ (baik), 56-75\% (cukup), dan nilai <55\% (kurang) (Sasongko et.al., 2019).

Kuesioner Hill-Bone telah diterjemahkan ke dalam versi bahasa Indonesia dan dilakukan uji validitas dan reliabilitas dinyatakan valid ( $\mathrm{r}$ hitung $>\mathrm{r}$ tabel) serta reliabel dengan nilai Chronbach Alfa 0,742 (Fauziah, 2019). Data dari kuesioner hill-bone setiap item pertanyaan terdiri dari 4 poin pilihan skala Likert yaitu untuk jawaban tidak pernah diberi skor 1, jawaban kadang-kadang diberi skor 2, jawaban sering diberi skor 3 dan jawaban selalu 
diberi skor 4. Hasil skoring akan diperoleh nilai minimal 14 dan maksimal 56. Skor yang lebih tinggi mencerminkan kepatuhan rendah (Dehghan et al., 2015). Kepatuhan diklasifikasikan menjadi tidak patuh dan patuh berdasarkan cut poin of mean jika skor > mean dikatakan tidak patuh, skor < mean dikatakan patuh (Chudiak et.al., 2017).

Hubungan pengetahuan terhadap kepatuhan terapi pasien dianalisis dengan program SPSS Statistics 21.0 for Windows menggunakan uji korelasi pearson. Data yang diinputkan adalah data numerik berupa skor pengetahuan dan skor kepatuhan. Apabila didapatkan nilai signifikansi $\mathrm{p}<0,05$ artinya ada hubungan yang signifikan antara variabel yang diuji. Namun, apabila didapatkan nilai signifikansi $\mathrm{p}<0,05$ artinya tidak ada hubungan yang signifikan antara variabel yang diuji. Arah hubungan antar variabel dapat dilihat dari nilai $r$, jika nilai $r$ postif artinya kenaikan nilai pada variabel bebas akan menyebabkan kenaikan nilai pada variabel terikatnya. Besarnya nilai $\mathrm{r}$ menentukan kekuatan hubungan antar variabel sebagai berikut 0,01-0,199 (sangat lemah); r 0,2-0,399 (lemah); 0,4-0,599 (sedang); 0,6-0,799 ( kuat), 0,81,00 (sangat kuat) (Dahlan,2012).

\section{Hasil dan Pembahasan}

\subsection{Karakteristik responden}

Penelitian ini melibatkan sebanyak 85 responden. Data karakteristik responden diperoleh dari kuesioner yang kemudian dikonfirmasi dengan catatan rekam medis. Distribusi pasien dikelompokkan berdasarkan jenis kelamin, usia, pendidikan dan pekerjaan dapat dilihat pada Tabel 1.

Tabel 1. Distribusi karakteristik pasien hipertensi di Puskesmas Pucang Sawit Surakarta $(\mathrm{N}=85)$.

\begin{tabular}{cccc}
\hline $\begin{array}{c}\text { Karakteristik } \\
\text { Respoden }\end{array}$ & Klasifikasi & Jumlah & Persentase (\%) \\
\hline \multirow{2}{*}{ Jenis Kelamin } & Perempuan & 70 & $82,4 \%$ \\
& Laki-laki & 15 & $17,6 \%$ \\
\hline \multirow{3}{*}{ Usia (tahun) } & $36-45$ & 10 & $11,8 \%$ \\
& $46-55$ & 35 & $41,2 \%$ \\
& $56-65$ & 25 & $29,4 \%$ \\
& $>65$ & 15 & $17,6 \%$ \\
\hline \multirow{2}{*}{ Pendidikan } & SD & 37 & $43,5 \%$ \\
& SMP & 17 & $20 \%$ \\
& SMA & 7 & $8,2 \%$ \\
& Perguruan Tinggi & 8 & $9,5 \%$ \\
& Lain-lain & 16 & $18,8 \%$ \\
\hline \multirow{2}{*}{ Pekerjaan } & Tidak Bekerja & 15 & $17,6 \%$ \\
& Swasta/Wiraswasta & 45 & $52,9 \%$ \\
& PNS & 2 & $2,4 \%$ \\
& Ibu rumah tangga & 23 & $27,1 \%$ \\
\hline
\end{tabular}

Responden pasien hipertensi Puskesmas Pucang Sawit Surakarta terbanyak adalah perempuan, usia 46-55 tahun berpendidikan akhir SD yang pekerjaannya rata-rata ibu rumah 
tangga (Tabel 1). Hasil ini sesuai dengan data Dinas Kesehatan Kota Surakarta pada tahun 2017 yang menyebutkan mayoritas pasien hipertensi di Pucang Sawit adalah perempuan. Kelompok usia lansia akhir lebih banyak karena adanya peningkatan risiko hipertensi pada usia 30-50 tahun, biasanya akan muncul hipertensi idiopatik dan akan meningkat seiring dengan pertambahan usia (Kishore et al., 2016). Responden peneltian ini didominasi oleh responden dengan tingkat pendidikan rendah (SD), hal ini sejalan dengan penelitian lain yang menyebutkan bahwa hipertensi lebih tinggi insidensinya pada kelompok pendidikan rendah, tetapi tidak berbeda signifikan karena ada faktor lain yang berpengaruh seperti gaya hidup, genetik dan lingkungan (Olesen et al., 2012).

\subsection{Gambaran tingkat pengetahuan dan kepatuhan terapi hipertensi responden}

Penelitian ini menilai pengetahuan yang terkait tentang klasifikasi tekanan darah dan target terapi, faktor risiko terkait hipertensi, life style modification, dan penggunaan obat. Tabel 2 menunjukan gambaran pengetahuan responden berdasarkan persentase jawaban benar. Pengetahuan pasien terkiat jangka waktu terapi serta target terapi tergolong paling rendah $(29,41 \%)$. Informasi terkait kontrol tekanan darah dan target terapi merupakan informasi yang harus disampaikan kepada pasien hipertensi terutama pada awal terapi baik oleh dokter maupun apoteker pada saat pemberian informasi obat. Secara umum, target terapi antihipertensi pada pasien usia $<60$ tahuan adalah $<140 / 90 \mathrm{mmHg}$ sedangkan pada usia $>60$ tahun adalah <150/90 mmHg (Hernandez-Vila, 2015; James et al., 2014). Pengetahuan responden yang tergolong tinggi adalah terkait dengan tekanan darah yang dikategorikan hipertensi serta gaya hidup yang mendukung terapinya. Hasil penelitian ini menunjukan bahwa masih diperlukannya edukasi kepada masyarakat khususnya penderita hipertensi di Pucang Sawit tentang jangka waktu pengobatan, pentingnya kontrol rutin dan target terapi serta risiko komplikasi yang dapat terjadi akibat tidak terkontrolnya tekanan darah.

Gambaran kepatuhan responden dalam minum obat antihipertensi,diet garam dan kunjungan ke dokter dapat dilihat pada Tabel 3. Hasil riskesdas 2018 menyatakan bahwa banyak penduduk $(59,8 \%)$ dalam pengobatan hipertensi yang merasa sudah sehat. Kondisinya lebih baik atau merasa sudah sehat merupakan salah satu alasan ketidakpatuhan pasien dalam melakukan pengobatan (Safri et al., 2014). Mayoritas responden penelitian $(52,2 \%)$ tidak pernah lupa minum obat antihipertensi. dan sebagian (32,6\%) kadang-kadang memutuskan tidak minum obat dengan sengaja. Faktor yang menjadi penyebab pasien tidak patuh dalam minum obat antara lain adalah pasien kehabisan obat, pasien merasa sehat, dan malas. 
Tabel 2. Gambaran tingkat pengetahuan pasien hipertensi di Puskesmas Pucang Sawit Surakarta.

\begin{tabular}{lc}
\hline \multicolumn{1}{c}{ Kategori pertanyaan } & \% Jawaban benar \\
\hline Tekanan darah seseorang yang dikategorikan hipertensi & 78,82 \\
Pengobatan hipertensi dapat diberikan tunggal atau kombinasi & \\
berdasarkan target tekanan darah & 44,70 \\
Pentingnya kontrol tekanan darah secara rutin & 60 \\
Hipertensi tidak terkontrol berisiko menyebabkan gagal ginjal & 64,70 \\
Hipertensi tidak terkontrol berisiko menyebabkan stroke & 52,94 \\
Hubungan tekanan darah tinggi dengan serangan jantung & 38,82 \\
Pengaruh berat badan dengan penurunan tekanan darah & 45,52 \\
Olahraga yang direkomendasikan pada pasien hipertensi & 67,05 \\
Konsumsi makanan mengandung serat tinggi bermanfaat & \\
mendukung terapi hipertensi & 77,64 \\
Jangka waktu terapi hipertensi & 29,41 \\
Target tekanan darah & 29,41 \\
\hline
\end{tabular}

Tabel 3. Gambaran kepatuhan pasien hipertensi di Puskesmas Pucang Sawit Surakarta berdasarkan kuesioner Hill-Bone (Keterangan: 1= tidak pernah; 2= kadangkadang; $3=$ sering; 4= selalu).

\begin{tabular}{|c|c|c|c|c|}
\hline \multirow[t]{2}{*}{ Pertanyaan } & \multicolumn{4}{|c|}{$\begin{array}{c}\text { Persentase jawaban responden } \\
\qquad(\%)\end{array}$} \\
\hline & 1 & 2 & 3 & 4 \\
\hline \multicolumn{5}{|l|}{ Kepatuhan Responden dalam Minum Obat Antihipertensi } \\
\hline 1. Seberapa sering Anda lupa minum obat antihipertensi? & 52,2 & 41,3 & 6,5 & - \\
\hline $\begin{array}{l}\text { 2. Seberapa sering Anda pernah memutuskan untuk tidak } \\
\text { minum obat antihipertensi? }\end{array}$ & 50 & 32,6 & 17,4 & - \\
\hline $\begin{array}{l}\text { 3. Seberapa sering Anda tidak mengambil obat antihipertensi } \\
\text { yang sudah diresepkan oleh dokter? }\end{array}$ & 91,4 & 4,3 & 4,3 & - \\
\hline 4. Seberapa sering Anda kehabisan obat antihipertensi? & 39,1 & 50 & 10,9 & - \\
\hline $\begin{array}{l}\text { 5. Seberapa sering Anda tidak minum obat antihipertensi } \\
\text { sebelum pergi kedokter? }\end{array}$ & 43,5 & 41,3 & 10,9 & 4,3 \\
\hline $\begin{array}{l}\text { 6. Seberapa sering Anda tidak minum obat antihipertensi saat } \\
\text { Anda merasa sehat? }\end{array}$ & 52,2 & 28,3 & 15,2 & 4,3 \\
\hline $\begin{array}{l}\text { 7. Seberapa sering Anda tidak minum obat anti hipertensi } \\
\text { saat Anda merasa sakit? }\end{array}$ & 87 & 10,9 & 2,1 & - \\
\hline $\begin{array}{l}\text { 8. Seberapa sering Anda minum obat antihipertensi milik } \\
\text { orang lain? }\end{array}$ & 93,5 & 6,5 & - & - \\
\hline $\begin{array}{l}\text { 9. Seberapa sering Anda tidak minum obat antihipertensi saat } \\
\text { merasa malas? }\end{array}$ & 91,3 & 4,3 & 4,4 & - \\
\hline \multicolumn{5}{|l|}{ Kepatuhan Responden dalam Diet Garam } \\
\hline 10. Seberapa sering Anda mengonsumsi makanan yang asin? & 17,4 & 54,3 & 28,3 & - \\
\hline $\begin{array}{l}\text { 11. Seberapa sering Anda menambahkan garam ke dalam } \\
\text { makanan sebelum Anda memakannya? }\end{array}$ & 30,4 & 52,2 & 17,4 & - \\
\hline 12. Seberapa sering Anda mengonsumsi makanan cepat saji? & 45,7 & 45,7 & 8,6 & - \\
\hline \multicolumn{5}{|l|}{ Kepatuhan untuk Melakukan Kunjungan ke Dokter } \\
\hline $\begin{array}{l}\text { 13. Seberapa sering Anda tidak datang untuk kontrol tekanan } \\
\text { darah? }\end{array}$ & 37 & 47,8 & 15,2 & - \\
\hline
\end{tabular}


Pembatasan konsumsi garam masih sulit dilakukan oleh responden. Sebanyak 28,3\% responden masih sering makan makanan yang asin. dan 52,2\% responden kadang-kadang masih menambahkan garam. Konsumsi garam yang tinggi dapat menyebabkan terjadinya peningkatan retensi air sehingga akan berisiko meningkatkan tekanan darah. Asupan garam natrium telah diteliti berkaitan dengan terjadinya hipertensi. Hasil studi menunjukkan bahwa pembatasan konsumsi garam dapat menurunkan tekanan darah sistolik secara signifikan (Grillo et al., 2019).

Kepatuhan yang diukur pada penelitian ini, tidak hanya terkait dengan terapi tetapi juga kepatuhan melakukan kontrol ke dokter. Tabel 3 menunjukan bahwa sebagian besar responden jarang kembali ke Puskesmas untuk kontrol tekanan darah (47,8\%). Motivasi yang rendah merupakan salah satu faktor penyebab ketidakpatuhan. Motivasi dapat dipengaruhi oleh tingkat pendapatan pasien, karena untuk melakukan kunjungan ke dokter membutuhkan biaya (Rajasati et al., 2014). Kepatuhan yang rendah termasuk faktor penghambat kontrol yang baik, kepatuhan pasien sangat berpengaruh terhadap keberhasilan terapi yang dijalani.

\subsection{Hubungan pengetahuan dan kepatuhan terapi hipertensi responden}

Skor pengetahuan masing-masing pasien dihitung berdasarkan jumlah jawaban benar kemudian dihitung persentase jawaban benar dibandingkan dengan total skor maksimal dikalikan $100 \%$. Pengetahuan responden diklasifikasikan menjadi 3 yaitu pengetahuan baik jika skor $>75 \%$, pengetahuan cukup jika skor 56-75\%, dan pengetahuan kurang jika skor < $55 \%$ (Sasongko et al., 2019). Gambaran pengetahuan responden tentang hipertensi dapat dilihat pada Tabel 2. Hasil skoring kepatuhan menunjukan skor minimal 14, maksimal 20 dan rata-rata $20,11 \pm 3,40$. tingkat kepatuhan ditetapkan berdasarkan skor rata-rata, nilai $<20,11$ dikategorikan patuh dan >20,11 dikategorikan tidak patuh.

Tabel 4. Klasifikasi pengetahuan dan kepatuhan pasien hipertensi di Puskesmas Pucang Sawit Surakarta. Uji korelasi dilakukan menggunakan metode Pearson correlation.

\begin{tabular}{|c|c|c|c|c|c|c|c|}
\hline \multirow{3}{*}{ Pengetahuan } & \multicolumn{4}{|c|}{ Kepatuhan } & \multirow{2}{*}{\multicolumn{2}{|c|}{ Total }} & \multirow{3}{*}{$\begin{array}{c}\text { Uji } \\
\text { Korelasi }\end{array}$} \\
\hline & \multicolumn{2}{|c|}{ Tidak patuh } & \multicolumn{2}{|c|}{ Patuh } & & & \\
\hline & frekuensi & $\begin{array}{c}\text { persentase } \\
(\%)\end{array}$ & frekuensi & $\begin{array}{c}\text { persentase } \\
(\%)\end{array}$ & frekuensi & $\begin{array}{c}\text { persentase } \\
(\%)\end{array}$ & \\
\hline Baik & 4 & 4,71 & 6 & 7,06 & 10 & 11,77 & \\
\hline Cukup & 12 & 14,12 & 10 & 11,76 & 22 & 25,88 & $p: 0,319$ \\
\hline kurang & 25 & 29,41 & 28 & 32,94 & 53 & 62,35 & r : 0,109 \\
\hline Total & 41 & 48,24 & 44 & 51,76 & 85 & 100,0 & \\
\hline
\end{tabular}

Hasil penelitian yang disajikan Tabel 4 menunjukan bahwa sebagain besar responden $(62,35 \%)$ mempunyai tingkat pengetahuan yang kurang terhadap penyakit hipertensi. Penelitian serupa yang mengukur tingkat pengetahuan pasien hipertensi telah di lakukan sebelumnya di Puskesmas wilayah Malang diperoleh hasil sebagian besar responden pasien 
hipertensi memiliki pengetahuan yang baik (Pramestutie \& Silviana, 2016). Berbeda dengan di Malang, studi tingkat pengetahuan pasien hipertensi di kota Bandung menunjukan hasil bahwa sebagian besar responden memiliki pengetahuan cukup (Sinuraya et al., 2017). Studi lain, pada populasi pasien di rumah sakit tipe A menunjukkan bahwa mayoritas pasien mempunyai tingkat pengetahuan yang cukup (Aulia, 2018). Hal ini menunjukan bahwa tingkat pengetahuan pasien hipertesni bervariasi tergantung pada populasinya.

Mayoritas responden penelitian mempunyai tingkat pendidikan rendah, sedangkan dari sisi pengetahuan didominasi dengan tingkat pengetahuan kurang. Hasil studi lain menunjukan bahwa ada hubungan antara tingkat pendidikan dengan pengetahuan responden (Dewi \& Farida, 2018). Hal ini telah sesuai dengan teori, semakin tinggi tingkat pendidikan seseorang maka pengetahuannya semakin baik. Ada kemungkinan bahwa tingkat pendidikan rendah memiliki pengetahuan yang baik, karena dapat mengakses informasi dari berbagai media sehingga pengetahuannya dapat meningkat (Sihombing, 2017).

Tingkat pengetahuan yang tinggi menunjukkan seseorang telah mengetahui, mengerti, dan memahami maksud dari pengobatan yang telah dijalani. Pengetahuan merupakan salah satu faktor yang dikaitkan dengan kepatuhan pasien (Rahayu et al., 2021). Sebagian besar responden memiliki pengetahuan yang kurang, tetapi mayoritas responden patuh terhadap terapi antihipertensi yang dijalani. Hasil ini berbeda dengan beberapa penelitian sebelumnya yang menyebutkan bahwa pengetahuan berpengaruh terhadap kepatuhan pasien hipertensi (Aulia, 2018; Rahayu et al., 2021; Rajasati et al., 2014). Selain pengetahuan ada faktor-faktor lain yang berpengaruh terhadap kepatuhan pasien hipertensi yaitu motivasi untuk berobat, dukungan keluarga, dan status pekerjaan (Rajasati et al., 2014).

Hasil uji korelasi pearson menggunakan SPSS Statistics 21.0 for Windows didapatkan nilai signifikansi p-value sebesar $0,319(>0,05)$ menujukkan bahwa tidak ada hubungan signifikansi antara pengetahuan dengan kepatuhan terapi hipertensi di Puskesmas Pucangsawit Surakarta. Besarnya korelasi antara pengetahuan dan kepatuhan adalah 0,109. Menurut tingkat keeratan antara variabel bebas dan variabel terikat menunjukkan bahwa ada hubungan yang sangat rendah. Hasil analisis nilai $r$ menunjukan hubungan positif antar variabel artinya semakin besar nilai satu variabel, maka semakin besar juga nilai variabel lainnya (Dahlan, 2012). Semakin tinggi pengetahuan akan semakin tinggi kepatuhan terapi hipertensi responden Puskesmas Pucangsawit Surakarta. Pengetahuan penderita hipertensi akan sangat berpengaruh pada sikap untuk patuh kontrol karena semakin tinggi pengetahuan keinginan untuk kontrol juga semakin meningkat (Annisa et al., 2014). Penelitian lain menyebutkan bahwa tingkat pengetahuan yang tinggi meningkatkan kepatuhan pasien dalam 
terapi hipertensi (Rahayu et al., 2021; Sianturi et al., 2020). Perbedaan karakteristik populasi menyebabkan hasil penelitian tersebut berbeda dengan penelitian ini.

Keterbatasan pada penelitian ini adalah, tidak melakukan analisis terkait motivasi dan dukungan keluarga terhadap kepatuhan sebagai faktor pendukung kepatuhan. Penelitian serupa dapat dilakukan dengan menambahkan analisis faktor yang berpengaruh terhadap kepatuhan selain pengetahuan.

\section{Kesimpulan}

Hasil penelitian ini dapat disimpulkan bahwa ada korelasi positif tetapi tidak signifikan antara pengetahuan dengan kepatuhan terapi pasien hipertensi di Puskesmas Pucang Sawit Surakarta tahun $2019(p=0,319 ; \mathrm{r}=0,109)$.

\section{Ucapan Terimakasih}

Terimakasih penulis sampaikan kepada Dinas Kesehatan Surakarta dan Puskesmas Pucangsawit Surakarta atas data dan arahan yang diberikan untuk mendukung penelitian ini.

\section{Deklarasi Konflik Kepentingan}

Penulis adalah tim editor jurnal, tetapi tidak ada konflik kepentingan dalam proses review. Artikel diproses sesuai dengan aturan yang berlaku pada jurnal.

\section{Daftar Pustaka}

Annisa, A, Fitria Nur; Wahiduddin, Ansar, dan Jumriani. (2014). Faktor Yang Berhubungan DenganKepatuhan Berobat Hipertensi Pada Lansia Di Puskesmas Pattingalloang Kota Makassar, Skripsi, Fakultas Farmasi Universitas Hassanudin.

Aulia, R. (2018). Pengaruh Pengetahuan Terhadap Kepatuhan Pasien Hipertensi Di Instalasi Rawat Jalan RSUD Dr. Moewardi Surakarta Periode Februari - April 2018. In Publikasi Ilmiah Skripsi. Farmasi Universitas Muhammadiyah Surakarta (Issue April).

Bina, D., Komunitas, F., Klinik, D. A. N., Bina, D., Dan, K., Kesehatan, A., dan Kesehatan, D. (2006). Pharmaceutical care, Jakarta : Departemen Kesehatan Republik Indonesia.

Chudiak, A., Jankowska-Polańska, B., dan Uchmanowicz, I. (2017). Effect of frailty syndrome on treatment compliance in older hypertensive patients. Clinical Interventions in Aging, 12, 805-814. https://doi.org/10.2147/CIA.S126526.

Dahlan, S. M. (2012). Statistik untuk Kedokteran dan Kesehatan. Jakarta : Salemba Medika.

Dehghan, M., Nayeri, N. D., dan Iranmanesh, S. (2015). Validating the Persian Version of the Hill-Bone's Scale of "Compliance to High Blood Pressure Therapy." Journal of Advances in Medicine and Medical Research, 235-246. https://doi.org/10.9734/10.9734/BJMMR/2015/13061.

Dewi, M. A. C., dan Farida, Y. (2018). Tingkat Pengetahuan Pasien Rawat Jalan Tentang Penggunaan Antibiotika di Puskesmas Wilayah Karanganyar. JPSCR: Journal of Pharmaceutical Science and Clinical Research, 3(1), 27. https://doi.org/10.20961/jpscr.v3i1.15102.

Fauziah, F. (2019). Validitas Reliabilitas Kuesioner Hill-Bone Versi Bahasa Indonesia Pada Pasien Hipertensi. Skripsi, Universitas Jember. 16-77.

Ghembaza, M., Senoussaoui, Y., Tani, M., dan Meguenni, K. (2014). Impact of patient knowledge of hypertension complications on adherence to antihypertensive therapy. Current Hypertension Reviews, 10(1), 41-48. https://doi.org/10.2174/157340211001141111160653. 
Grillo, A., Salvi, L., Coruzzi, P., Salvi, P., dan Parati, G. (2019). Sodium Intake and Hypertension. Nutrients, 11(9), 1-16. https://doi.org/10.3390/NU11091970.

Hernandez-Vila, E. (2015). A Review of the JNC 8 Blood Pressure Guideline. Texas Heart Institute Journal, 42(3), 226. https://doi.org/10.14503/THIJ-15-5067.

Iyalomhe, G. B. S., dan Iyalomhe, S. I. (2010). Hypertension-related knowledge, attitudes and life-style practices among hypertensive patients in a sub-urban Nigerian community. Journal of Public Health and Epidemiology, 2(4), 71-77. http://www.academicjournals.org/jphe.

James, P. A., Oparil, S., Carter, B. L., Cushman, W. C., Dennison-Himmelfarb, C., Handler, J., Lackland, D. T., LeFevre, M. L., MacKenzie, T. D., Ogedegbe, O., Smith, S. C., Svetkey, L. P., Taler, S. J., Townsend, R. R., Wright, J. T., Narva, A. S., dan Ortiz, E. (2014). 2014 Evidence-based guideline for the management of high blood pressure in adults: Report from the panel members appointed to the Eighth Joint National Committee (JNC 8). In JAMA - Journal of the American Medical Association (Vol. 311, Issue 5, pp. 507-520). American Medical Association. https://doi.org/10.1001/jama.2013.284427.

Jankowska-Polańska, B., Uchmanowicz, I., Dudek, K., dan Mazur, G. (2016). Relationship between patients' knowledge and medication adherence among patients with hypertension. Patient Preference and Adherence, 10, 2437-2447. https://doi.org/10.2147/PPA.S117269.

Kementrian Kesehatan. (2019). Pedoman Pelayanan Kefarmasian Pada Hipertensi. Jakarta : Kementrian Kesehatan.

Kishore, J., Gupta, N., Kohli, C., dan Kumar, N. (2016). Prevalence of Hypertension and Determination of Its Risk Factors in Rural Delhi. International Journal of Hypertension, 2016. https://doi.org/10.1155/2016/7962595.

Liberty, I. A., Pariyana, P., Roflin, E., dan Waris, L. (2017). Determinan Kepatuhan Berobat Pasien Hipertensi Pada Fasilitas Kesehatan Tingkat I. Jurnal Penelitian Dan Pengembangan Pelayanan Kesehatan, 1(1), 58-65. https://doi.org/10.22435/JPPPK.V1I1.428.

Mesmer, B., Stéphane, M., Drame, B., dan Bwira, B. (2013). Global Journal Of Medicine And Public Health Patients-related predictors of poor adherence to antihypertensive treatment in Congo-Brazzaville: a cross-sectional study. Global Journal of Medicine and Global Health. Kaboru, B. Global Journal of Medicine and Global Health Www.Gjmedph.Org, 2(5), 1-9. http://urn.kb.se/resolve?urn=urn:nbn:se:oru:diva-34019.

Olesen, K., Carneiro, I. G., Jørgensen, M. B., Rugulies, R., Rasmussen, C. D. N., Søgaard, K., Holtermann, A., dan Flyvholm, M. A. (2012). Associations between psychosocial work environment and hypertension among non-Western immigrant and Danish cleaners. International Archives of Occupational and Environmental Health, 85(7), 829-835. https://doi.org/10.1007/s00420-011-0728-2.

Pramestutie, H. R., dan Silviana, N. (2016). The Knowledge Level of Hypertension Patients for Drug Therapy in the Primary Health Care of Malang. Indonesian Journal of Clinical Pharmacy, 5(1), 26-34. https://doi.org/10.15416/ijcp.2016.5.1.26.

Rahayu, E. S., Wahyuni, K. I., dan Anindita, P. R. (2021). Hubungan Tingkat Pengetahuan Dengan Kepatuhan Pasien Hipertensi Di Rumah Sakit Anwar Medika. Jurnal Ilmiah Farmasi Farmasyifa, 4(1), 87-97. https://doi.org/10.29313/jiff.v4i1.6794.

Rajasati, P. Q., Raharjo, B. B., dan Ningrum, D. N. A. (2014). Faktor-Faktor Yang Berhubungan Dengan Kepatuhan Pengobatan Pada Penderita Hipertensi Di Wilayah Kerja Puskesmas Kedungmundu Kota Semarang. Unnes Journal of Public Health, 4(3), $16-23$.

Safri, F. M., Sukartini, T., dan Ulfiana, E. (2014). Analisis Faktor Yang Berhubungan Dengan Kepatuhan Minum Obat Pasien Tb Paru Berdasarkan Health Belief Model di Wilayah 
Kerja Puskesmas Umbulsari, Kabupaten Jember. Indonesian Journal of Community Health Nursing, 2(2).12-21.

Sasongko, H., Dompas, T. I. T., dan Farida, Y. (2019). The influence of giving information and its factors affecting the knowledge level of antibiotics use in temanggung regency. Indian Journal of Public Health Research and Development, 10(3), 839-842. https://doi.org/10.5958/0976-5506.2019.00605.3.

Sianturi, S. R., Dilianty, O. M., dan Marlina, P. W. (2020). Hubungan Tingkat Pengetahuan Dengan Kepatuhan Berobat Penderita Hipertensi Di Puskesmas Nagi Kecamatan Larantuka Kabupaten Flores Timur. Jurnal Ilmiah Kesehatan Keperawatan, 15(2), 5563. https://doi.org/10.26753/JIKK.V15I2.305.

Sihombing, M. (2017). Faktor yang Berhubungan dengan Hipertensi pada Penduduk Indonesia yang Menderita Diabetes Melitus (Data Riskesdas 2013). Buletin Penelitian Kesehatan, 45(1), 53-64. https://doi.org/10.22435/BPK.V45I1.5730.53-64.

Sinuraya, R. K., Siagian, B. J., Taufik, A., Destiani, D. P., Puspitasari, I. M., Lestari, K., dan Diantini, A. (2017). Assessment of Knowledge on Hypertension among Hypertensive Patients in Bandung City: A Preliminary Study. Indonesian Journal of Clinical Pharmacy, 6(4), 290-297. https://doi.org/10.15416/ijcp.2017.6.4.290.

Statistika, B. P. (2018). Profil Kesehatan Provinsi Jawa Tengah 2017. Badan Pusat Statistika Jawa Tengah. https://jateng.bps.go.id/publication/download.html?nrbvfeve=MDM5MmEzODFiNzFj MmJjOGY3MDhmNzk0\&xzmn=aHR0cHM6Ly9qYXRlbmcuYnBzLmdvLmlkL3B1Y mxpY2F0aW9uLzIwMTgvMDgvMDMvMDM5MmEzODFiNzFjMmJjOGY3MDhmN zk0L3Byb2ZpbC1rZXNlaGF0YW4tcHJvdmluc2ktamF3YS10ZW5nYWgtMjAxNy5od G1s\&twoadfnoarfeauf=MjAyMS0xMS0wMyAxOToyMzo1NQ\%3D\%3D.

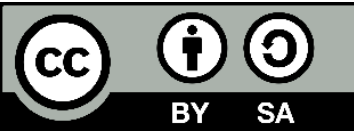

(C) 2021 by the authors. Submitted for possible open access publication under the terms and conditions of the Creative Commons Attribution-ShareAlike 4.0 International (CC BY-SA 4.0) license (https://creativecommons.org/licenses/by-sa/4.0/). 